\title{
Eleições na ABEn
}

EDITORIAL

\section{Maria Goretti David Lopes}

Presidente Nacional da Associação Brasileira de Enfermagem (2007-2010). Brasília, DF

Em 20 10, ocorre mais um processo eleitoral no âmbito da Associação Brasileira de Enfermagem (ABEn), marcado pela maturidade política e democracia interna estabelecidas na entidade, Que elegerá, simultaneamente, a Diretoria Nacional e a Diretoria das Seções e Regionais para a gestão 20 10-2013. A próxima gestão da ABEn terá a responsabilidade de manter a agenda institucional; garantir sustentabilidade ao projeto político e profissional da Enfermagem brasileira; promover o fortalecimento político, administrativo, organizacional e técnico-operacional da entidade; e encontrar novas estratégias para o enfrentamento das Questões Que importem à nossa profissão e ao país.

$\mathrm{Na}$ Educação, atuar firmemente para inibir o crescimento desordenado do número de cursos de enfermagem descompromissados com a Qualidade na formação dos futuros profissionais; fortalecer o Fórum Nacional de Educação das Profissões na Área de Saúde (FNEPAS) e o Conselho Consultivo Nacional de Escolas de Enfermagem vinculadas à ABEn. Assim, a missão da ABEn é de continuar investindo em processos de formação e educação permanente, Que possibilitem a construção de um paradigma centrado no cuidado e na Qualidade de vida.

Na área de Publicações e Comunicação, investir cada vez mais na Qualidade da REBEn e do Jornal ABEn; consolidar o Fórum Nacional de Editores de Publicações Científicas de Enfermagem e estreitar os meios de comunicação com seus associados. Já o Centro de Estudos e Pesquisas em Enfermagem (CEPEn) continuará a organizar e a dar vida ao Centro de Memória da Enfermagem Brasileira; e a fomentar e participar do debate para o desenvolvimento da política de produção, divulgação e consumo do conhecimento de Enfermagem, mantendo a parceria com os representantes do CNPQ, CAPES e BVS - Enfermagem.

A Diretoria de Assuntos Profissionais se empenhará em tornar realidade a constituição da Subcomissão de Sistematização da Prática de Enfermagem em todas as Seções e Regionais, como órgão de assessoria da ABEn no desenvolvimento de projeto científico e político Que visa a construção de terminologias de Enfermagem e à capacitação profissional para sua utilização; e na implementação de ações voltadas para o desenvolvimento, implantação e utilização efetiva de uma linguagem especializada nos sistemas de documentação e informação da prática profissional. A Diretoria Científico-Cultural deverá apoiar e estimular os enfermeiros especialistas/assistenciais na elaboração de projetos e protocolos Que envolvam novas tecnologias de Enfermagem para a promoção da saúde e um novo modelo de atenção; e na divulgação de experiências bem sucedidas em diferentes ambientes da prática profissional.

Com a Federação Nacional de Enfermeiros (FNE) e Conselho Federal de Enfermagem (COFEN) o desafio é incrementar a Agenda Política de Entendimentos com propostas de interesse da profissão, nos campos do trabalho, educação, pesQuisa e assistência de enfermagem. Acima de tudo, a ABEn deverá criar estratégias para a formação política dos integrantes da profissão para, inclusive, transformar a atual conjuntura de exclusão da enfermagem, categoria hegemonicamente feminina, e das mulheres dos espaços de poder e decisão.

A apropriação do espaço político pelas mulheres por meio de cotas nas direções partidárias, por exemplo, vai depender do grau de sua organização. Entendendo Que os partidos políticos são imprescindíveis para a democracia, para a disputa de poder e como canal de mediação entre sociedade e o poder constituído do estado. Embora a dinâmica da sociedade seja intensa e os partidos políticos tenham dificuldade para acompanhá-la, é por meio desse instrumento que se estrutura a democracia e é legitimada a representação política. É necessário, contudo, mudar a lógica conservadora existente nos partidos, bem como na sociedade em geral, de que é "natural" Que apenas os homens estejam no centro das decisões políticas.

Em 2010, com as eleições gerais no Brasil para escolha do Presidente da República, senadores, governadores, deputados federais e deputados estaduais, é quando as/os brasileiras/os depositam nas urnas seus anseios por um estado, de fato, justo, democrático e que lhes garanta os direitos fundamentais, sobretudo os direitos sociais.

Será, portanto, fundamental promover o entendimento da Enfermagem sobre os valores da democracia, do exercício da cidadania e da liberdade; a Enfermagem frente a seus direitos e deveres; a intervenção da enfermagem na Política Nacional de Saúde e em outras políticas públicas.

A atuação dos trabalhadores da enfermagem, em um contexto de parceria com os demais profissionais da saúde, contribuirá para, cada vez mais, consolidar seu trabalho como prática social, essencial à assistência aos usuários e à organização e funcionamento do Sistema Único de Saúde (SUS).

A enfermagem brasileira saberá, com liberdade e autonomia, fazer suas próprias escolhas políticas. 